\title{
Multiple regression analysis to assess the contamination with metals and metalloids in surface sediments (Aveiro Lagoon, Portugal)
}

\section{Teodor Stoichev ${ }^{a \star}$, João Pedro Coelho ${ }^{b}$, Alberto De Diego ${ }^{c}$, Maria Gabriela Lobos Valenzuela $^{d}$, Maria Eduarda Pereira ${ }^{e}$, Aubin Thibault de Chanvalon ${ }^{f}$, David Amouroux $^{f}$}

anterdisciplinary Center of Marine and Environmental Research (CIIMAR/CIMAR), University of Porto, Terminal de Cruzeiros de Leixoes, Av. General Norton de Matos s/n, 4450-208 Matosinhos, Portugal

tstoichevbg@yahoo.com; Tel: +351 223401800

${ }^{\mathrm{b}}$ CESAM - Centre for Environmental and Marine Studies, Department of Biology, University of Aveiro, Campus Universitário de Santiago, 3810-193 Aveiro, Portugal

${ }^{\circ}$ Department of Analytical Chemistry, Faculty of Science and Technology, University of Basque Country, 48080, Bilbao, Spain

'Laboratory of Analytical and Environmental Chemistry, Institute of Chemistry and Biochemistry, University of Valparaíso, Valparaíso, Chile

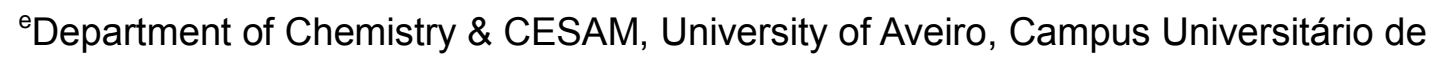
Santiago, 3810-193 Aveiro, Portugal

'Universite de Pau et des Pays de l'Adour, E2S UPPA, CNRS, IPREM, Institut des Sciences Analytiques et de Physico-chimie pour l'Environnement et les matériaux, Pau, France

\begin{abstract}
An innovative multiple regression analysis was used to evaluate metal/metalloid contamination in the surface sediments of a coastal lagoon. The concentrations of metals/metalloids were represented as a function of geochemical characteristics of the sediments (fine fraction, concentrations of organic carbon, $\mathrm{Ca}, \mathrm{Al}, \mathrm{Mn}$ ) and distances between sampling points. The
\end{abstract}


effect of distances on the concentrations were negligible for $\mathrm{Li}, \mathrm{Co}, \mathrm{Ni}, \mathrm{Ba}, \mathrm{V}, \mathrm{Cr}$, and only geochemical variables specific for each element explained its spatial variation. The concentrations of $\mathrm{As}, \mathrm{Cu}, \mathrm{Zn}$ and $\mathrm{Pb}$ were influenced by both geochemical and geographical distance variables, the latter representing the anthropogenic influence and the extent of transport of contaminants away from the upstream source. Enrichment of the sediment with $\mathrm{Ba}$, As, Co, $\mathrm{Cr}$ and $\mathrm{V}$ was determined mainly by enrichment with $\mathrm{Mn}$. The proposed approach is supplementary to the traditional utilization of enrichment factors, and is better suited for systems with anthropogenic influence.

Keywords: Metals; Coastal lagoon; Sediments; Multiple regression model; Contamination; Enrichment factor

\section{Introduction}

Estuarine catchments have been strategic settings throughout human history, either as places of navigation, agricultural abundance or as locations of the biggest cities in the World (Kennish 1996; McLusky and Elliot 2004). Usually used as repositories of industrial and domestic effluents, estuaries are the end-point of numerous contaminants, the vast majority of which tend to settle and are thus stored in estuarine and marine sediments (Laurier et al. 2003; Prego and Cobelo-Garcia 2003; Kim et al. 2004). Due to their toxicity to organisms and persistence in the environment, growing international consciousness has developed with regards to assessing the contamination status and protecting these ecosystems.

Traditionally, the dynamic of metals/metalloids in sediments is evaluated through the utilization of enrichment factors (EFs) (Abrahim and Parker 2008), but recently, novel methodologies have been developed to evaluate the composition and dynamics of sediment characteristics. For example, artificial neural networks combined with residual kriging has been used to predict the spatial distribution of $\mathrm{Cr}$ in soil (Tarasov et al. 2018). 
Multiple regression analysis allows for the verification of simple and higher order

effects of several explanatory variables and their interactions. Upon simplification of the starting models, only a few significant explanatory variables will remain. It has been applied recently to evaluate biogeochemical processes in estuarine water (Stoichev et al. 2016; 2020). Multiple regression was used to quantify major components of lake sediments by near infrared spectra (Russell et al. 2019) or to find out the relative importance of hydrous iron and manganese oxides on the retention of trace metals in estuarine sediments (Turner 2000). Multiple regression analysis has been successfully applied to study the behavior of $\mathrm{Hg}$ species in surface sediments from the Aveiro Lagoon (Stoichev et al. 2019). A relatively small area of the lagoon, the Laranjo Bay, suffered from chlor-alkali mercury pollution coming from a single upstream source (Pereira et al. 2009; Stoichev et al. 2019). However, sediment contamination in the system is not restricted to mercury, with reports of significant concentrations of other metals and metalloids, such as As, Pb, Zn (Costa and Jesus-Rydin 2001).

The aim of this work was to evaluate the effectiveness of multiple regression analysis to study spatial variations in heavy metal/metalloid concentrations in surface sediments from contaminated shallow tidal environments. One type of explanatory variables depended on geographical distances. Another type of variables was related to sediment geochemistry, which, in coastal environments, should include indicators of both terrestrial (e.g. Al or Fe) and oceanic (e.g. Ca) influence (Perez et al. 2016; Gredilla et al. 2015a; Dias et al. 2007). An attempt was made to separate and quantitatively evaluate the effects of contaminant dispersion from a point source from those of geochemical processes as a potential influence for spatial distribution of contamination. This is possible if additive statistical effects of some explanatory variables (responsible for metal/metalloid dispersion and for the geochemistry of the sediments) on the dependent variables (e.g. concentration of contaminant) are found. For this purpose, equations were developed modelling metal/metalloid concentrations depending on different distance variables or geochemical explanatory variables. 


\section{Experimental}

\subsection{Study area}

Aveiro Lagoon is a coastal lagoon in the North of Portugal (Fig. 1) comprised of a network of channels, opening into the Atlantic Ocean by way of a single narrow channel. The lagoon covers an area of $83 \mathrm{~km}^{2}$ at high tide (HT) and $66 \mathrm{~km}^{2}$ at low tide (LT) and has an average depth of $1 \mathrm{~m}$. The tidal range is minimum $0.6 \mathrm{~m}$ during neap tide; maximum $3.2 \mathrm{~m}$ during spring tide. The water residence time in the lagoon is approximately 2 days, however, it is more than two weeks in the contaminated area (Laranjo Bay, Fig. 1c)) (Dias et al. 2003). The particle residence time is approximately 2-3 days in the lower areas of the lagoon and up to 14 days in the upper ends (Dias et al. 2007). The Laranjo Bay is contaminated, not only with mercury (Pereira et al. 2009) but also with other metals/metalloids, like As, $\mathrm{Pb}, \mathrm{Zn}$ coming from pyrite solid waste (Costa and Jesus-Rydin 2001).

The Vouga River is the largest freshwater source to the Aveiro Lagoon. It covers a catchment area of around $3362 \mathrm{~km}^{2}$ and the main land uses, occupying 4/5 of the total area, being agriculture and forests (Stoichev et al. 2017). Acidic soil types have developed in the drainage area: mainly Umbrisol in the north and west and Umbrisol/Podzol in the south-west (ESBN 2005). The small and relatively homogeneous drainage area means the Aveiro Lagoon is probably not influenced by multiple terrestrial sources.

The annual air temperatures in the drainage area are relatively low and precipitation is high compared to other parts of Iberian Peninsula (AEMET-IM 2011). This microclimate leads to quite important average river discharge of Vouga $\left(50 \mathrm{~m}^{3} \mathrm{~s}^{-1}\right)$ in spite of the small catchment area (Stoichev et al. 2017). The Antuã River, suppling freshwater to Laranjo Bay, is the second largest freshwater source to the lagoon (average flow of only $5 \mathrm{~m}^{3} \mathrm{~s}^{-1}$ ). It is of primary importance for the export of contaminants from Laranjo Bay to the rest of the lagoon (Stoichev et al. 2018). 


\subsection{Sampling}

The sediment samples named from 1 to 14 were collected in the summer of 2010 , the remaining samples being collected during two further campaigns (February 2012 and August 2012) in order to estimate eventual seasonal change. Sites were located close to the lagoon entrance, in the main channels, near the main freshwater input and in the central area of the lagoon. Special emphasis was given to the Laranjo Bay, being near the contamination source. Samples were taken from intertidal flats, at low tide and during daylight from the top $5 \mathrm{~cm}$ layer with acid washed plastic utensils, stored in plastic bags and kept cool until arrival at the laboratory.

Each sampling point is characterized by geographical coordinates and falls within a simplified (in order to facilitate distance calculations) polygon border, marked with hyphen line (Fig. 1). For the spatial distribution of the contaminants, each point is characterized by the distances through water $d_{S}$ to suspected contamination source (S) and $d_{M}$ to mouth of the lagoon (M), obtained within the simplified polygon border (Fig. 1b). Alternatively; each sampling point may be described by the distance ratio $D R_{M}=d_{S} / d_{M}$. Each point was additionally characterized using distance $d_{R}$ to the reference point $\mathbf{R}$ (instead of $d_{M}$ ) obtained within the simplified polygon border or by reference distance ratio $D R_{R}=d_{S} / d_{R}$. More information can be found elsewhere (Stoichev et al. 2019).

\subsection{Chemical analysis}

At the laboratory, samples were freeze-dried (Unicryo $\mathrm{MC}-4 \mathrm{~L}-60^{\circ} \mathrm{C}$ ) then disaggregated and macrodetritus removed by dry sieving through a $2 \mathrm{~mm}$ mesh. Fine fraction (FF) content $(<63$ $\mu \mathrm{m})$ was quantified by wet sieving of sample aliquots under running water. Sediment organic matter (OM) was analyzed through loss on ignition ( $6 \mathrm{~h}$ at $500 \stackrel{\circ}{\circ})$.

Each sample was then grinded with agate mortar and sieved $(300 \mu \mathrm{m})$ before storage in darkness until analysis. Total carbon (TC), was quantified in a CHNS analyzer (Leco Truspec Micro). Organic Carbon (OC) was quantified with the same method, after carbonate 
removal according to the ISO 10694 standard. Sediment digestions for metal determination were performed according to US EPA 3051 protocol using microwave digestion with a mixture $(3 / 1, v / v)$ of hydrochloric (37\%, Sigma-Aldrich, p.a.) and nitric acids $(69 \%$, SigmaAldrich, p.a.). The metals ( $\mathrm{Ca}, \mathrm{Al}, \mathrm{Mn}, \mathrm{Fe}, \mathrm{Co}, \mathrm{Li}, \mathrm{Cu}, \mathrm{Cd}, \mathrm{Zn}, \mathrm{Ni}, \mathrm{Pb}, \mathrm{Ba}, \mathrm{V}$ and $\mathrm{Cr}$ ) were measured using inductively coupled plasma optical emission spectrometry (ICP-OES; Perkin-Elmer, model ICP Optima 2000 DV). The accuracy was checked using BCSS-1 marine sediment with measured values being between $98 \%$ and $102 \%$ of the certified ones.

The concentration of As in sediments (US EPA 3051A) was determined after microwave digestion with a mixture $(3 / 1, v / v)$ of nitric acid $(69 \%$, Sigma-Aldrich, p.a.) and hydrofluoric acid (40\%, Sigma-Aldrich, p.a.). Determinations of As were carried out using a quadrupole inductively coupled plasma mass spectroscopy (ICP-MS, Thermo Elemental, X-Series) equipped with a Peltier cooled impact bead spray chamber and a concentric Meinhard nebulizer. Parallel digestion and analyses of certified reference material MESS-3 were consistent with the certified value, with extraction efficiencies ranging from $93 \%$ to $109 \%$.

\subsection{Statistical treatment}

\subsubsection{Model building}

Cadmium was detected only in Laranjo Bay (5.78, 4.09 and $2.49 \mu \mathrm{mol} \mathrm{kg}{ }^{-1}$ at samples 1,2 and 5, respectively) and was not included in the statistical treatment. Statistical data treatment was carried out using $R$ software (R Core Team 2014). The dependent variables $Y$ (concentrations of $\mathrm{Co}, \mathrm{Li}, \mathrm{As}, \mathrm{Cu}, \mathrm{Zn}, \mathrm{Ni}, \mathrm{Pb}, \mathrm{Ba}, \mathrm{V}, \mathrm{Cr}$ ), were represented as functions of $q$ explanatory variables $\mathrm{X}_{\mathrm{i}}$. One type of explanatory variable is related to geographical coordinates (either both distances $d_{S}, d_{M}$ or their ratio $\left.D R_{M}\right)$. Additionally, other distances $\left(d_{S}\right.$, $d_{R}$ ) or their ratio $D R_{R}$ were used. A second set of explanatory variables represent the geochemical characteristics of the samples (FF, concentrations of $\mathrm{OM}, \mathrm{OC}, \mathrm{TC}, \mathrm{Al}, \mathrm{Mn}, \mathrm{Ca}$ ). The set of geochemical variables was selected after a preliminary inspection of the data. The concentrations of $\mathrm{Al}$ in sediments are an indicator of terrestrial processes (Perez et al. 2016; 
Gredilla et al. 2015a). The levels of Ca could be used as proxy for ocean contribution in sediments from the Aveiro Lagoon (Dias et al. 2007). The concentrations of Ca in sediments are anticorrelated with $d_{M}(r=-0.40, p<0.05)$. The concentration of $\mathrm{Mn}$ are correlated mainly with those of Fe $(r=0.58, p<0.001)$, less correlated with $\mathrm{Al}(r=0.48, p<0.01)$, TC $(r=0.45$, $p<0.02)$ and $O C(r=0.40, p<0.05)$ and not correlated with the carbonates (difference TC-OC). Sulfide phases commonly occurred in sediments from Aveiro Lagoon a few millimeters bellow the sediment surface and were associated with metals, like $\mathrm{Fe}, \mathrm{Mn}, \mathrm{Ni}$ and $\mathrm{Zn}$ (Martins et al. 2015). Therefore, Mn would be an indicator of Mn(IV) oxo-hydroxides (related to $\mathrm{Fe}$ (III) oxo-hydroxides) or sulfides in sediments from the Aveiro Lagoon. Manganese was preferred to $\mathrm{Fe}$ as an explanatory variable to avoid co-linearity with $\mathrm{Al}$ (Fe was highly correlated with $\mathrm{Al}, \mathrm{r}=0.82$ ). Organic matter, sulfides and oxo-hydroxides of $\mathrm{Mn}$ are recognized as scavengers of toxic metals in Aveiro Lagoon (Martins et al. 2015).

Both $Y$ and $X_{i}$ were normalized, when necessary, using density function graphical visualization and Box-Cox transformations (Bellanger and Tomassone 2014) to give variables $\mathrm{Y}_{\mathrm{T}}$ and $\mathrm{X}_{\mathrm{T}, \mathrm{i}}$. Some of the explanatory variables $\left(\mathrm{Al}, \mathrm{Mn}, \mathrm{TC}, d_{S}, d_{M}, d_{R}\right)$ and some of the dependent variables $(\mathrm{Co}, \mathrm{Li}, \mathrm{Ba}, \mathrm{V}, \mathrm{Cr})$ were not altered (identical transformation $\left(Y_{T}=\right.$ $Y)$ ), only the following transformations finally being selected:

$$
\begin{array}{lrr}
A s_{T}=\ln [A s] & P b_{T}=\ln [P b] & C u_{T}=\sqrt{[C u]} \\
Z n_{T}=\sqrt{[Z n]} & N i_{T}=\sqrt{[N i]} & \\
O M_{T}=\ln (O M) & F F_{T}=\sqrt{F F} & O C_{T}=\sqrt{O C} \\
D R_{M, T}=\ln \left(D R_{M}\right)=\ln \left(d_{S} / d_{M}\right) & D R_{R, T}=\left(D R_{R}\right)^{-0.5}=\sqrt{d_{R} / d_{S}}
\end{array}
$$

The relationship between the explanatory variables is expressed by $L_{1}, L_{2}$ or $L_{3}$, the index representing the highest interaction order, described in the starting model:

$$
L_{3}\left(X_{T, 1}, X_{T, 2}, \ldots, X_{T, i}, \ldots, X_{T, q}\right)=\sum_{i=1}^{q} a_{i} X_{T, i}+\sum_{i \neq j} a_{i, j} X_{T, i} X_{T, j}+\sum_{i \neq j \neq k} a_{i, j, k} X_{T, i} X_{T, j} X_{T, k}
$$




$$
L_{2}\left(X_{T, 1}, X_{T, 2}, \ldots, X_{T, i}, \ldots, X_{T, q}\right)=\sum_{i=1}^{q} a_{i} X_{T, i}+\sum_{i \neq j} a_{i, j} X_{T, i} X_{T, j}
$$

$L_{1}\left(X_{T, 1}, X_{T, 2}, \ldots, X_{T, i}, \ldots, X_{T, q}\right)=\sum_{i=1}^{q} a_{i} X_{T, i}$

The regression coefficients $a_{i}$ represent the simple terms for variable $X_{i}$. The coefficients $a_{i j}$ and $a_{i j k}$, account for the double and triple interactions, respectively. The starting models, used to describe element concentrations, can be written with the equations:

$$
\begin{aligned}
& Y_{T}=a_{0}+L_{2}\left(d_{S}, d\right)+L_{1}\left(d_{S}{ }^{2}, d^{2}, X_{T, i}\right) \quad \underline{\mathrm{X}}_{\mathrm{i}}: \mathrm{Mn}, \mathrm{Al}, \mathrm{Ca}, \mathrm{TC}, \mathrm{OC} \\
& Y_{T}=a_{0}+L_{2}\left(d_{S}, d\right)+L_{1}\left(d_{S}{ }^{2}, d^{2}, F F_{T}, C a_{T}, O M_{T}, M n, X_{T, i}\right) \quad \underline{X}_{i:} \text { Al, TC, OC } \\
& Y_{T}=a_{0}+L_{2}\left(d_{S}, d\right)+L_{1}\left(d_{S}{ }^{2}, d^{2}\right)+L_{2}\left(F F_{T}, X_{T, i}\right) \quad \underline{\mathrm{X}}_{\mathrm{i}:} \mathrm{Al}, \mathrm{TC}, \mathrm{OC} \\
& Y_{T}=a_{0}+L_{2}\left(D R_{T}, X_{T, i}\right)+L_{1}\left(D R_{T}^{2}\right) \quad \underline{\mathrm{X}}_{\mathrm{i}}: \mathrm{Mn}, \mathrm{Al}, \mathrm{Ca}, \mathrm{TC}, \mathrm{OC} \\
& Y_{T}=a_{0}+L_{1}\left(D R_{T}, D R_{T}^{2}, F F_{T}, C a_{T}, O M_{T}, M n, X_{T, i}\right) \quad \underline{X}_{i}: \text { Al, TC, OC } \\
& Y_{T}=a_{0}+L_{1}\left(D R_{T}, D R_{T}^{2}, A l, C a_{T}\right)+L_{2}\left(M n, F F_{T}, O M_{T}\right) \\
& Y_{T}=a_{0}+L_{1}\left(D R_{T}, D R_{T}^{2}\right)+L_{2}\left(F F_{T}, X_{T, i}\right) \quad \underline{\mathrm{X}}_{\mathrm{i}:} \mathrm{OC}, \mathrm{TC} \\
& Y_{T}=a_{0}+L_{3}\left(D R_{T}, F F_{T}, X_{T, i}\right)+L_{1}\left(D R_{T}^{2}\right) \quad \underline{\mathrm{X}}_{\mathrm{i}}: \mathrm{OC}, \mathrm{TC} \\
& Y_{T}=a_{0}+L_{1}\left(D R_{T}, D R_{T}^{2}\right)+L_{2}\left(M n, F F_{T}, X_{T, i}\right) \quad \underline{\mathrm{X}}_{\mathrm{i}}: \mathrm{Al}, \mathrm{TC}, \mathrm{OC} \\
& Y_{T}=a_{0}+L_{1}\left(D R_{T}, D R_{T}^{2}\right)+L_{2}\left(C a_{T}, F F_{T}, X_{T, i}\right) \quad \underline{\mathrm{X}}_{\mathrm{i}}: \mathrm{Al}, \mathrm{TC}, \mathrm{OC} \\
& Y_{T}=a_{0}+L_{2}\left(C a_{T}, M n, F F_{T}, X_{T, i}\right) \quad \underline{X}_{i}: \text { Al, TC, OC, OM }
\end{aligned}
$$

Eqs. 3-5 searched $Y$ as a function of $d_{S}$ and $d$ (either $d_{M}$ or $d_{R}$ ) while Eqs 6-12 used $D R$ (either $D R_{M}$ or $D R_{R}$ ). Numerous geochemical characteristics were checked simultaneously without accounting for interaction effects (Eqs. 4, 7). Some of the starting equations accounted for interactions between distances (Eqs. 3-5), between geochemical variables (Eqs. 5, 8, 9, 11, 12 13) or between $D R$ and geochemical variables (Eqs 6, 10). Quadratic effects of distances and of $D R$ were checked in all starting models, except in Eq. 13, where distance variables were not present. Moderate correlations were found (all data) between Al and $\mathrm{FF}_{\mathrm{T}}(\mathrm{r}=0.44)$ or between $\mathrm{Mn}$ and $\mathrm{FF}_{\mathrm{T}}(\mathrm{r}=0.40)$ but very high correlations were observed 
for $\mathrm{Al}-\mathrm{TC}(\mathrm{r}=0.92)$ and $\mathrm{Al}-\mathrm{OC}_{\mathrm{T}}(\mathrm{r}=0.89)$. Therefore, the variables $\mathrm{Al}, \mathrm{OC}$ and $\mathrm{TC}$ were never considered together in order to avoid problems with co-linearity (Stoichev et al. 2019).

\subsubsection{Model simplification and selection}

The coefficients $a_{0}$ (intercept), $a_{i}, a_{i j}, a_{i j k}$ were determined using multiple regression analysis (Crawley 2007). The models were simplified by leaving only the coefficients significantly different from $0(p<0.05$ for the interaction terms and $p<0.1$ for the simple effects). The number of the considered coefficients in the starting equations never exceeded 11 in order to avoid overparametrization.

Firstly, the minimal adequate model was developed using all available data $(n=32)$. Secondly, the applicability of the obtained model was checked after removing values of $Y$ higher than 95th percentile $\left(\mathrm{P}_{0.95}\right)$ of all data and the regression coefficients for the minimal adequate model were determined again with the remaining dataset (short data, $n=30$ ). The obtained regression equation, using the short data, were extrapolated for data removed (extrapolated data, $n=2$ ). The minimal adequate model was considered further only if robust, meaning the same significant terms were obtained for all data and for short data. The extrapolated data includes only sites, sampled in summer 2010, and are mainly situated in Laranjo Bay: samples 1, 5 (for As, Cu); samples 1, 3 (for $\mathrm{Cr}, \mathrm{Ni}$, V); samples 1, 2 (Zn); 1, 11 $(\mathrm{Pb}) ;$ 1, $10(\mathrm{Co}) ; 3,13(\mathrm{Ba})$ and 3, $7(\mathrm{Li})$.

All models were compared using graphical representation of model values $Y_{M}$ against experimental ones $\mathrm{Y}_{\mathrm{E}}$ and by root mean square deviation $(R M S D)$ criteria (for all data, short data and extrapolated data) representing how far the model values differ when compared with $n$ experimental data of $Y$ :

$R M S D=\sqrt{\frac{\sum\left(Y_{E, i}-Y_{M, i}\right)^{2}}{n}}$ 
Among the best models (for the dependence $Y_{M}=f\left(Y_{E}\right)$ slope close to 1 , intercept close to 0) the simplest ones were selected, especially those lacking interaction terms between distance and geochemical explanatory variables:

$Y_{T}=a_{0}+f_{g e o}($ geochemistry $)+f($ distances $)=Y_{G e o, T}+f($ distances $)$

\subsubsection{Effect of geochemistry}

For models with additive effects of distance and geochemical variables, the effect of geochemistry on the spatial distribution of a contaminant away from a point source could be estimated using enrichment indexes (EI). Those indexes are defined, for each sample and for each dependent variable $\mathrm{Y}$, as ratios between experimental values $\mathrm{Y}_{\mathrm{E}}$ (which presumably depend both on geographical distances and on geochemistry) and geochemical component $Y_{\text {Geo }}$ (Eq. 15), the last being obtained upon inverse transformation (Eq. 1) of $Y_{\text {Geo,T. }}$

$\mathrm{EI}=Y_{E} / Y_{G e o}$

The results obtained from the El are compared with enrichment factors (EF) in which concentrations of a chemical element $\mathrm{Me}$ are normalized with Al concentrations, both for the sample and for the local background levels (LBL):

$E F=\frac{([M e] /[A l])_{s a m p l e}}{([M e] /[A l])_{L B L}}$

LBLs were calculated using $3 s$ and $4 s$ methods, where $s$ is the standard deviation from concentrations (Gredilla et al. 2015b). The LBLs are calculated as $90^{\text {th }}$ percentiles from data contained within average \pm 3 s intervals, or as averages from data contained within average \pm 4 s intervals, for $3 \mathrm{~s}$ and $4 \mathrm{~s}$ methods, respectively. Further, average EF from $3 \mathrm{~s}$ and 4s methods will be used. Calculations were carried out using LBL as reference because usually the global values, such as metal/metalloid concentration in the upper continental crust (UCC), do not reflect local conditions (Birch 2017).

\section{Results and discussion}




\subsection{Potential existence of seasonal trends}

Analysis of covariance ANCOVA (season, geochemical variables) for surface sediments from the Aveiro Lagoon (nine samples taken in February and August 2012) demonstrated that seasonal trends for $Y_{E}$ (metal/metalloid concentrations) were not observed (results not shown). When, for some sampling sites, winter / summer differences existed, they followed concentration changes observed for geochemical variables $X_{i}$. For example, the concentrations of As could be expressed by a combination of TC and the product TC $x \mathrm{Ca}$. The concentrations of $\mathrm{Zn}$ depended on $\mathrm{Al}, \mathrm{Mn}$ and $\mathrm{Al} \times \mathrm{Mn}$ and those of $\mathrm{Cu}-$ on $\mathrm{Al}, \mathrm{Ca}$ and $\mathrm{Al} \times \mathrm{Ca}$. The concentrations of $\mathrm{Li}$ and $\mathrm{Pb}$ were determined only by Al. The rest of $\mathrm{Y}_{\mathrm{E}}(\mathrm{V}, \mathrm{Co}$, $\mathrm{Ba}, \mathrm{Ni}, \mathrm{Cr}$ ) depended on $\mathrm{Al}$ and $\mathrm{Ca}$. Therefore, for subsequent treatment of the spatial variation, no seasonal differences were considered.

\subsection{Modelling spatial distribution of metals and metalloids}

Average values (bold), standard deviations and ranges (italic) for FF and concentrations of OC, TC, OM and metals/metalloids in surface sediments from Laranjo Bay and from the rest of the Aveiro Lagoon, as well as LBLs, are shown in Table 1. The average values of the dependent variables $\mathrm{Y}$ (concentrations of $\mathrm{Co}, \mathrm{Li}, \mathrm{As}, \mathrm{Cu}, \mathrm{Zn}, \mathrm{Ni}, \mathrm{Pb}, \mathrm{Ba}, \mathrm{V}$ and $\mathrm{Cr}$ ) are always higher in Laranjo Bay compared to the rest of the lagoon. This difference was between 1.57 and 2.14 times for $\mathrm{Co}, \mathrm{Li}, \mathrm{Ni}, \mathrm{V}, \mathrm{Ba}, \mathrm{Cr}$ and between 3.46 and 5.06 times for As, $\mathrm{Cu}, \mathrm{Zn}, \mathrm{Pb}$. The concentrations of metals tend to decrease with $d_{S}$ (Fig. 2), the coefficients of correlation always being negative, between $r=-0.45(\mathrm{p}<0.02)$ for $\mathrm{Pb}$ and $\mathrm{Ba}$ and $r=-0.61(p<0.001)$ for $\mathrm{Zn}$ and $\mathrm{Li}$. It is suspected that some of the elements might come from a point anthropogenic source (both geochemical and geographical distance variables being important) while for others only geochemical explanatory variables will finally be included in the minimal adequate models.

Only minimal adequate models that show the same significant terms for all data and short data are considered. However, among the obtained robust models, some were generally worse than others and were not considered further. Such examples include all 
equations where distances $d_{S}$ or $d$ were present, or where there was only one of the geochemical variables FF, OC, TC, OM, Ca, Mn. Generally, a model in which $D R_{M}$ was present produced similar results, or worse, than a model that used $D R_{R}$ as the explanatory variable. The minimal adequate models with $\mathrm{RMSD}$ values for $\mathrm{Co}, \mathrm{Li}, \mathrm{As}, \mathrm{Cu}, \mathrm{Zn}, \mathrm{Ni}, \mathrm{Pb}, \mathrm{V}$, $\mathrm{Ba}, \mathrm{Cr}$ using all data, short data and extrapolated data are presented in online resources. Models with the lowest RMSD values (marked in bold in Tables ESM 1 to ESM 10, online resources) are further considered. The model values $Y_{M}$ are graphically compared with the experimental values $Y_{E}$ in Figs. ESM 1, ESM 2, ESM 3, the slope and intercept of $Y_{M}=f\left(Y_{E}\right)$ and the models adjusted $\mathrm{R}^{2}$ values also being given in the online resources. Only robust models (the same for all data and short data) that can extrapolate the concentrations of metals/metalloids (Figs. ESM 1, ESM2, ESM3) are further considered. Since extrapolated data concerns only sites sampled once in summer 2010, the effects of distances and geochemistry could be studied with the proposed robust equations using all sampling campaigns and are independent of site replication. The extrapolation was clearly seen for As, $\mathrm{Cu}, \mathrm{Pb}, \mathrm{Ni}, \mathrm{Zn}$ and $\mathrm{Cr}$, where the models for short data could be applied for concentrations at least 1.5-2.2 times higher than the maximum values. Similar approach, applied to other contaminants in sediments from the Aveiro Lagoon has led to even higher extrapolation of concentration: at least 8.0 and 3.0 times for inorganic mercury and methylmercury, respectively (Stoichev et al. 2019).

The best models, described with the following equations, were selected based on their simplicity, especially the lack of interactions between geochemical and distance variables. For the sake of brevity, when, in some of the equations, $f\left(D R_{R}\right)$ appears, this stands for:

$$
f\left(D R_{R}\right)=-a_{1} \sqrt{d_{R} / d_{S}}+a_{1,1} d_{R} / d_{S}
$$

For Co and $\mathrm{Li}$, only geochemical variables were found significant and predicted similar concentrations to experimental ones, according to Eqs. 19 and 20, respectively 
(online resources, Figs. ESM 1g, ESM 3e). Therefore, the dependence on $D R_{R}$ and the Els

for these elements were not studied:

$$
\begin{aligned}
& {[\mathrm{Co}]=a_{6}[\mathrm{Al}]+a_{8}[\mathrm{Mn}]+\left(a_{3}-a_{2,3} \sqrt{F F}\right) \ln [\mathrm{OM}]} \\
& {[\mathrm{Li}]=[\mathrm{Al}]\left(a_{6}-a_{6,7} \ln [\mathrm{Ca}]\right)}
\end{aligned}
$$

For $\mathrm{As}, \mathrm{Cu}, \mathrm{Zn}, \mathrm{Ni}, \mathrm{Pb}, \mathrm{V}, \mathrm{Ba}$ and $\mathrm{Cr}$, robust and extrapolatable models with additive effects of $D R_{R}$ and geochemical variables were obtained, $Y_{\mathrm{M}}$ being very close to $\mathrm{Y}_{\mathrm{E}}$ (online resources):

$$
\begin{aligned}
& \ln [A s]=a_{0}+f\left(D R_{R}\right)+\sqrt{[O C]}\left(a_{4,8}[M n]-a_{4}\right)+\sqrt{F F}\left(a_{2}-a_{2,8}[M n]\right) \\
& \sqrt{[C u]}=f\left(D R_{R}\right)+a_{6}[A l]+a_{7} \ln [C a] \\
& \sqrt{[Z n]}=f\left(D R_{R}\right)+a_{2} \sqrt{F F}+[M n]\left(a_{8}+a_{5,8}[T C]-a_{2,8} \sqrt{F F}\right) \\
& \sqrt{[N i]}=a_{0}+f\left(D R_{R}\right)+a_{6}[A l]+\sqrt{F F}\left(a_{2}-a_{2,6}[A l]\right) \\
& \ln [P b]=a_{0}+f\left(D R_{R}\right)+a_{2} \sqrt{F F}+[T C]\left(a_{5}-a_{2,5} \sqrt{F F}\right) \\
& \ln [P b]=a_{0}+a_{1,1,1}\left(d_{R} / d_{S}\right)^{3 / 2}+a_{2} \sqrt{F F}+[A l]\left(a_{6,7} \ln [C a]-a_{2,6} \sqrt{F F}\right) \\
& {[V]=a_{0}-a_{1,1} d_{R} / d_{S}+a_{6}[A l]+\left(a_{3}-a_{2,3} \sqrt{F F}\right) \ln [O M]} \\
& {[B a]=-a_{1,1} d_{R} / d_{S}+a_{6}[A l]+a_{7} \ln [C a]} \\
& {[C r]=f\left(D R_{R}\right)+a_{6}[A l]+a_{8}[M n]+\sqrt{F F}\left(a_{2}-a_{2,6}[A l]\right)}
\end{aligned}
$$

For example, the slopes of $Y_{M}=f\left(Y_{E}\right)$ for all data were between 0.92 and 1.03 for all studied elements, except $\mathrm{Pb}$, and the origins were indistinguishable from 0 (online resources). Lower slope (0.80, all data) was obtained for Pb (Eq. 25, Fig. ESM 3b). A possible reason is the existence of other contamination sources in the lagoon downstream of Laranjo Bay. Relatively high concentrations of $\mathrm{Pb}$ were found in sample $11\left(0.106 \mathrm{mmol} \mathrm{kg}^{-1}\right)$ as well as in GAF in summer and winter (0.026 and $0.050 \mathrm{mmol} \mathrm{kg}^{-1}$, respectively). In that zone, higher concentrations of $\mathrm{Pb}$ have been measured in sediments, compared to the central area of the lagoon (Velez et al. 2016). These samples are situated close to seafood processing industry / port activities that can eventually be a source of metal contamination. Alternatively, they may suffer influence from the Aveiro city channels, recognized as a source of $\mathrm{Pb}$ for the 
sediments (Martins et al. 2013, 2015). An attempt to improve the model, accounting for another $\mathrm{Pb}$ source, was undertaken by introducing into the starting models (Eqs. 6-12) an additional cubic term, $\left(D R_{R}\right)^{3}$, without interaction of this term with the other explanatory variables (Table ESM 7). As a result, the slope of the dependence $Y_{M}=f\left(Y_{E}\right)$ increased from 0.80 to 0.85 (all data, Eq. 26, Fig. ESM 3f) and this dependence was used further to study the influence of $D R_{R}$ and geochemical variables on $\mathrm{Pb}$ concentration. However, the Els for $\mathrm{Pb}$ were not calculated because the model values tend to be slightly lower than the experimental values.

Contour plots of model and experimental values of $\mathrm{As}, \mathrm{Cu}, \mathrm{Zn}$ and Ni concentrations (Eqs 21-24) are shown in Fig. 3 and of Pb, V, Ba and Cr (Eqs. 26-29) - in Fig. 4. For each element, the effect of specific geochemical function $f_{\text {geo }}$ (on $y$ axis) are separated from distance function (on $\mathrm{x}$ axis). The behavior of $\mathrm{As}, \mathrm{Cu}, \mathrm{Zn}$ and $\mathrm{Pb}$ depended on both geochemical and distance functions. Although a slight increase in Ni concentration was observed near the contamination source, the isolines tended to be parallel to the $x$ axis and therefore Ni was mainly determined by geochemical variables. The effect of the distances on $\mathrm{V}, \mathrm{Ba}$ and $\mathrm{Cr}$ is negligible (despite the presence of $d_{S}$ and $d_{R}$ in Eqs. 27-29). As confirmation, for $\mathrm{Ni}, \mathrm{V}, \mathrm{Ba}$ and $\mathrm{Cr}$, there were also good models describing the concentrations as functions of only geochemical variables (Figs. ESM 3c,g, ESM 2a,e):

$$
\begin{aligned}
& \sqrt{[\mathrm{Ni}]}=a_{0}+a_{6}[\mathrm{Al}]+\sqrt{F F}\left(a_{2}-a_{2,6}[\mathrm{Al}]\right) \\
& {[\mathrm{V}]=a_{6}[\mathrm{Al}]+\sqrt{F F}\left(a_{2}+a_{2,6}[\mathrm{Al}]\right)} \\
& {[\mathrm{Ba}]=a_{0}+a_{2} \sqrt{F F}+a_{6}[\mathrm{Al}]+a_{7} \ln [\mathrm{Ca}]} \\
& {[\mathrm{Cr}]=a_{6}[\mathrm{Al}]+\sqrt{F F}\left(a_{2,8}[\mathrm{Mn}]-a_{2,6}[\mathrm{Al}]\right)}
\end{aligned}
$$

The values and standard errors of the regression coefficients for Eqs. 19-33 are presented in online resources, showing similarity of the regression coefficients for all data and short data models. The calculation of Els (Eqs. 15, 16) is intended to distinguish between geochemical and distance explanatory variables. The dependence of $\mathrm{EI}(\mathbf{a}, \mathbf{b})$ and $\mathrm{EF}(\mathbf{c}, \mathbf{d})$ on the $d_{S}$ for metals/metalloids in surface sediments is shown in Fig. 5. The results for the EF are more 
dispersed compared with the El. For $\mathrm{Ni}, \mathrm{V}, \mathrm{Ba}$ and $\mathrm{Cr}$, the Els are close to 1 and do not depend on $d_{S}$ (Fig. 5a). Thus, despite their higher concentrations in sediments from Laranjo Bay, compared to the rest of the Aveiro Lagoon (Table 1), the influence of a potential point source upstream could not be proven for these metals. Only for As, $\mathrm{Cu}$ and $\mathrm{Zn}$ could the influence of an upstream contamination source be suspected from Els (Fig. 5b). The Els for $\mathrm{Pb}$ were not calculated but the existence of a strong contamination source upstream of Laranjo Bay was demonstrated from the contour plots (Fig. 4 a,b) as well as from the calculation of the EFs (Fig. $5 \mathrm{~d}$ ). Therefore, for $\mathrm{As}, \mathrm{Cu}, \mathrm{Zn}$ and $\mathrm{Pb}$, the results from the Laranjo Bay (samples 1-5, LAR, Fig. 1c) were excluded from further consideration of the EFs, thus eliminating the influence of spatial distribution of contaminants away from the point source, from the geochemical results.

\subsection{Effect of geochemical variables}

The multiple regression analysis demonstrated that, for some of the elements (e.g. $\mathrm{V}$ and $\mathrm{Ni}$ ) Al was the geochemical variable present in almost all final equations. Terrestrial processes with simultaneous erosion of $\mathrm{Al}$ and $\mathrm{Fe}$ are involved in the transport of these metals, as indicated by the high correlation between $\mathrm{Al}$ and Fe concentrations ( $r=0.82)$. Participation of oxo-hydroxides of $\mathrm{Fe}$, obtained after chemical erosion, in the retention of those metals is another possibility. Additional processes are possible, as demonstrated by the additive effects of Mn concentration on the behavior of $\mathrm{Co}$ (Eq. 19) and $\mathrm{Cr}$ (Eq. 29) in the sediments. The terrestrial and marine influence could be involved in the case of $\mathrm{Cu}$ and $\mathrm{Ba}$ since additive effects of $\mathrm{Al}$ and $\mathrm{Ca}$ concentrations were observed in the minimal adequate models (Eqs. 22, 28).

While OC has concentrating effects on metals/metalloids, the influence of TC is more ambiguous. In coastal sediments, some metals, such as Mn, sometimes co-precipitate with carbonates (Ho et al. 2010) but more frequently carbonates exhibit dilution effect (Basaham et al. 2006; Yücesoy and Ergin 1992). Positive additive effect of TC ( $\left.a_{5}>0\right)$ was observed in 
Aveiro Lagoon sediments for $\mathrm{Co}$, Li, Cu, Ni, Pb, V, Ba, Cr (Tables ESM 1, ESM 2, ESM4, ESM 6 - ESM 10, respectively) and therefore, TC in Aveiro Lagoon has the same carrier effect as OC. The difference TC-OC representing carbonates (negative values for samples $4,5,6,8,9$ and BAR (winter) replaced by 0 ) was not correlated with concentrations of any of the metals/metalloids considered. In Aveiro Lagoon, carbonates (average $0.30 \% \mathrm{C}$, maximum $0.86 \% \mathrm{C}$ ) had negligible contribution to TC (Table 1) and no effects of carbonates on metal/metalloid concentrations in sediments could be observed.

Values of LBL for metals/metalloids in sediments from the Aveiro Lagoon are compared (Table 2) with LBLs in sediments from Atlantic coast of Europe but mostly from Iberian Peninsula (Gredilla et al. 2015a; Corredeira et al. 2008; Carballeira et al. 2000; Coynel et al. 2016). For sediments from Cávado estuary (situated only $100 \mathrm{~km}$ north from Aveiro), the LBLs were estimated, by the same $3 \mathrm{~s}$ and $4 \mathrm{~s}$ methods as in the present study, using available data (Gredilla et al. 2015a). For Cr, Co, Zn and Ni, the LBLs for Aveiro Lagoon and for Cávado sediments are very similar. The sediments from Aveiro Lagoon compared with those from Cávado were naturally more enriched with As and V (about 5.3 and 3.1 times, respectively). On the contrary, Cávado sediments have LBL values of Cu and $\mathrm{Pb}$ about 3.5 and 3.2 times higher, compared to Aveiro Lagoon. The mean values and ranges of $\mathrm{LBL}$ for $\mathrm{Co}, \mathrm{As}, \mathrm{Cu}, \mathrm{Zn}, \mathrm{Ni}, \mathrm{Pb}$ and $\mathrm{Cr}$ in marine sediments worldwide were also summarized in Table 2 (Birch 2017). The LBLs in Aveiro Lagoon are similar to the values reported in the world marine sediments but for $\mathrm{Co}, \mathrm{Ni}, \mathrm{Pb}$ are situated in the lower part of the world range.

The EFs for Mn and Ca showed similar behavior, decreasing with both OC and with V/Co molar ratio, especially rapid decrease being observed at low OC contents (Fig. ESM 4 $a, b$, online resources). The average values (ranges) for molar ratios of redox sensitive elements $\mathrm{Ni} / \mathrm{Co}$ and $\mathrm{V} / \mathrm{Cr}$ were $2.22(0.32-3.96)$ and $1.22(0.92-1.53)$, respectively, and possibly the surface sediments from the Aveiro Lagoon are oxic. Dissolved $\mathrm{O}_{2}$ usually remains high in the lagoon waters even during summer (Lopes and Silva 2006). Deposition in oxic conditions occurs if $\mathrm{Ni} / \mathrm{Co}<5$ and $\mathrm{V} / \mathrm{Cr}<2$, as demonstrated for marine sediments 
(Martinez-Ruiz et al. 2015) and sedimentary rocks (Rimmer 2004). Among other redox sensitive elements, $\mathrm{V}$ is particularly responsive to changes in sediment redox properties (Martinez-Ruiz et al. 2015). The molar ratio V/Cr was dependent neither on OC nor on V/Co, while $\mathrm{Ni} / \mathrm{Co}$ ratio increased with $\mathrm{V} / \mathrm{Co}(r=0.52, p<0.01$, Fig. ESM $4 \mathrm{c}, \mathrm{d})$. For the surface sediments of the Aveiro Lagoon, the relationships between Me/Mn molar ratios (Me is the studied metal/metalloid) and V/Co had higher $R^{2}$ compared with similar dependencies of $\mathrm{Me} / \mathrm{Mn}$ with $\mathrm{Ni} / \mathrm{Co}$ ratios (results not shown). Therefore, for the studied samples, V/Co has similar significance to $\mathrm{Ni} / \mathrm{Co}$, but is preferred to $\mathrm{Ni} / \mathrm{Co}$ due to better relationships with the $\mathrm{Me} / \mathrm{Mn}$ ratios.

In sediments, metals/metalloids could be bound to $\mathrm{Mn}$ oxohydroxides, as demonstrated for As (Mil-homens et al. 2013; Telfeyan et al. 2017), V (Huang et al. 2015; Tribovillard et al. 2006), Ni, Co, Cu, Zn, Cr (Tribovillard et al. 2006). In oxic conditions, Ba can precipitate as $\mathrm{BaSO}_{4}$ and demonstrates similar behavior to that of $\mathrm{Mn}$ (Tribovillard et al. 2006). The sediments whose contamination was related to their proximity to the point source have no correlation between EF of the studied elements and EF of $\mathrm{Mn}$. In contrast, the others samples from Aveiro Lagoon show a strong correlation of EF for some elements with EF of Mn. The dependence is especially strong for As, Ba and Co (Fig. 6 a,c, r=0.94 for Ba and As, 0.90 for Co, 0.62 for $\mathrm{Cr}, 0.58$ for $\mathrm{V}$ ). Similar dependences, as those in Fig. 6, occur for $\mathrm{EF} \mathrm{Me}_{\mathrm{Al}}$ as a function of $\mathrm{EF} \mathrm{Ca} \mathrm{Al}_{\mathrm{Al}}$ (shown on Fig. ESM 5) but with lower correlation coefficients for the case of $\mathrm{Ba}$, As and Co. Generally, the EFs of $\mathrm{As}, \mathrm{Ba}, \mathrm{Co}, \mathrm{Cr}$ and V were inversely related with $\mathrm{OC}$ (Fig. 6 b,d). Starting from the continental source (at $E F_{M n}<0.8$, $\mathrm{n}=12$ ), the $\mathrm{EF}$ of As increased 16 times, from $0.47 \pm 0.10$ to 7.5 . For $\mathrm{Ba}$ and Co, the increase was from $0.98 \pm 0.08$ and $0.92 \pm 0.07$, respectively, to approximately 2.9 . The effect was less significant for $\mathrm{Cr}$ and $\mathrm{V}$ : from $0.97 \pm 0.08$ for both to 1.6 and 1.5 , respectively.

$$
E F M e_{A l}=c_{0}+c_{1} E F M n_{A l} \quad \text { Me: As, Ba, Co, Cr, V }
$$




$$
\left(\frac{[\mathrm{Me}]}{[\mathrm{Al}]}\right)_{\text {sample }}=c_{0}^{\prime}+c_{1}^{\prime}\left(\frac{[\mathrm{Mn}]}{[\mathrm{All}]}\right)_{\text {sample }}
$$

The values for the intercept $c_{0}^{\prime}$ and the slope $c_{1}^{\prime}$ (Eq. 34a) for As, Ba, Co, Cr and V are given in Table 3. The intercept for As was 0 due to non-linear effects of the slower increase of EF of As at low EF of Mn (Fig. 6 c).

Therefore, the contamination of sediment can occur through two different pathways. First, the relationship with distance indicates direct deposition of contaminated slurry. Second, the correlation supports an intense scavenging of $\mathrm{As}, \mathrm{Ba}$ and $\mathrm{Co}$ during estuarine Mn recycling. Hence, the linear relationship between EF (Eq. 34) suggests a mixing of a terrigeneous endmember with an endogenous $\mathrm{Mn}$ oxo-hydroxide precipitate endmember, probably produced during the reoxidation of efflux of dissolved $\mathrm{Mn}$, coming from the reducing part of the sediment (Thibault de Chanvalon et al. 2016). This mechanism represents a credible opportunity for As, Ba and Co to co-precipitate in the newly formed Mn oxyhydroxide. Note that this second pathway of contamination, based on our dataset, results in more contaminated sediment, situated relatively far from the contamination source (EF of As up to 7.5 versus 2.6 for slurry deposition, Fig. 5 b,d). Moreover, the importance of the redox dynamic is underlined by the lower correlation of the EF of the two redox elements analyzed $(\mathrm{Cr}$ and $\mathrm{V})$ with the EF of $\mathrm{Mn}$. These redox elements are not contaminants of the point source and their EFs are highly correlated (EFs for Cr and V, $r=0.85$ ).

For the concentrations of As in the sediments, the geochemical component $Y_{\text {Geo }}$ (Eq. 16) included Mn, TC and FF rather than Al (Eq. 21). The enrichment of sediments with As is determined by $\mathrm{EF}_{\mathrm{Mn}}$ but not by other conditions (e.g. V/Co ratio). Indeed, the behavior of As is different from that of the other elements since the concentration ratio As/Mn does not depend on V/Co ratio, while for all other studied elements $(\mathrm{Cu}, \mathrm{Zn}, \mathrm{Pb}, \mathrm{Ba}, \mathrm{Cr}, \mathrm{Co}, \mathrm{Ni}, \mathrm{V})$ there was an increasing trend of $\mathrm{Me} / \mathrm{Mn}$ with $\mathrm{V} / \mathrm{Co}$ ratio (Fig. 7). Strong correlations were found between V/Co ratio and V/Mn ( $r=0.82), \mathrm{Ba} / \mathrm{Mn}(\mathrm{r}=0.81), \mathrm{Cr} / \mathrm{Mn} \quad(\mathrm{r}=0.75), \mathrm{Cu} / \mathrm{Mn}$ ( $r=0.73), \mathrm{Co} / \mathrm{Mn}(\mathrm{r}=0.70), \mathrm{Ni} / \mathrm{Mn}(\mathrm{r}=0.64), \mathrm{Pb} / \mathrm{Mn}(\mathrm{r}=0.58)$ and $\mathrm{Zn} / \mathrm{Mn}(\mathrm{r}=0.51, \mathrm{p}<0.02)$. Similar 
to As, in the oxic water, $\mathrm{V}$ is present as vanadate anion (Huang et al. 2015) but, in surface sediments from the Aveiro Lagoon, $V$ demonstrates similar behavior to some metallic cations. While the adsorption of vanadate would increase the binding of metal cations, the binding of other oxoanions, such as arsenate, will be hindered (Huang et al. 2015).

\section{Conclusions}

The metal/metalloids, coming from a single upstream source, were suspected of contaminating surface sediments from a shallow coastal lagoon. Multiple regression analysis demonstrated that, from the studied chemical elements, only $\mathrm{As}, \mathrm{Cu}, \mathrm{Zn}$ and $\mathrm{Pb}$ were influenced both by geochemical and geographical distance variables, the latter representing the anthropogenic influence and the extent of transport of contaminants away from the upstream source. It is possible that for $\mathrm{Pb}$, an additional source within the lagoon exists. The concentrations for the rest of the metals $(\mathrm{Ni}, \mathrm{Li}, \mathrm{V}, \mathrm{Ba}, \mathrm{Cr}$, $\mathrm{Co}$ ) were determined by geochemical variables, the geographical distance being less significant or even non-existent in the final equations. By multiple regression analysis, specific geochemistry effects of one or more explanatory variables were found for the studied elements. The usefulness of enrichment indexes to study the spatial distribution of contaminants away from a point source was demonstrated. The proposed approach is supplementary to the traditional utilization of enrichment factors in order to study the dynamic of metals/metalloids in sediments. Enrichment of the sediment with $\mathrm{Ba}, \mathrm{As}, \mathrm{Co}, \mathrm{Cr}$ and $\mathrm{V}$ was determined mainly by enrichment with $\mathrm{Mn}$, whose sediment recycling favors As scavenging and could represent an overlooked but more intense pathway for As contamination. Additionally, the binding of $\mathrm{Ba}, \mathrm{Co}, \mathrm{Cr}$ and $\mathrm{V}$ was increased at higher $\mathrm{V} / \mathrm{Co}$ molar ratios in sediments. Enrichment with $\mathrm{Cu}, \mathrm{Ni}, \mathrm{Pb}$ and $\mathrm{Zn}$ were higher in sediments with high V/Co molar ratio but were rather independent of enrichment with $\mathrm{Mn}$.

\section{Acknowledgement}

This research was supported by national funds through FCT (Foundation for Science and Technology (Portugal) within the scope of UIDB/04423/2020 and UIDP/04423/2020. The 
financial support of European SUDOE Interreg IVB Program through the Orque-Sudoe project and of FONDECYT project (1150855) is acknowledged. João Pedro Coelho is funded by CESAM (UIDP/50017/2020+UIDB/50017/2020) and the Integrated Program of SR\&TD 'Smart Valorization of Endogenous Marine Biological Resources Under a Changing Climate' (Centro-01-0145-FEDER-000018), co-funded by Centro 2020 program, Portugal 2020 and the European Regional Development Fund.

\section{References}

Abrahim GMS, Parker RJ (2008) Assessment of heavy metal enrichment factors and the degree of contamination in marine sediments from Tamaki Estuary, Auckland, New Zealand. Environ Monit Assess 136: 227-238

AEMET-IM (2011) Iberian Climate Atlas, Air temperature and precipitation (1971-2000). Ministerio de medio ambiente y medio rural y marino (Spain), Instituto de meteorologia (Portugal)

Basaham AS, Rifaat AE, El-Sayed MA, Rasul N (2006) Sharm Obshur: Environmental consequences of 20 years of uncontrolled coastal urbanization. JKAU: Mar Sci 17: 129-152

Bellanger L, Tomassone R (2014) Data Exploration and Statistical Methods: Data Analysis and Data Mining Using R. Paris, Ellipses (in French)

Birch GF (2017) Determination of sediment metal background concentrations and enrichment in marine environments: A critical review. Sci Total Environ 580: 813-831

Carballeira A, Carral E, Puente X, Villares R (2000) Regional-scale monitoring of coastal contamination. Nutrients and heavy metals in estuarine sediments and organisms on the coast of Galicia (northwest Spain). Int J Environ Pollut $13: 534-572$

Corredeira C, Araújo MF, Jouanneau JM (2008) Copper, zinc and lead impact in SW Iberian shelf sediments: An assessment of recent historical changes in Guadiana river basin. Geochem $\mathrm{J}$ 42: 319-329

Costa C, Jesus-Rydin C (2001) Site investigation on heavy metal contaminated ground in Estarreja Portugal. Eng Geol 60: 39-47

Coynel A, Gorse L, Curti C, Schafer J, Grosbois C, Morelli G, Ducassou E, Blanc G, Maillet GM , Mojtahid M (2016) Spatial distribution of trace elements in the surface sediments of a major European estuary (Loire Estuary, France): Source identification and evaluation of anthropogenic contribution. J Sea Res 118: 77-91

Crawley MJ (2007) The R book, Wiley, Chichester

Dias JM, Abrantes I, Rocha F (2007) Suspended Particulate Matter Sources and Residence Time in a Mesotidal Lagoon. J. Coastal Res SI50: 1034-1039 
Dias JM, Lopes JF, Dekeyser I (2003) A numerical system to study the transport properties in the Ria de Aveiro lagoon. Ocean Dyn 53: 220-231

ESBN (2005) European Soil Bureau Network, Soil Atlas of Europe, European Commission, Office for Official Publications of the European Communities, L-2995 Luxembourg, pp. 128

Gredilla A, Stoichev T, Fdez-Ortiz de Vallejuelo S, Rodriguez-Iruretagoiena A, de Morais P, Arana G, de Diego A, Madariaga JM (2015a) Spatial distribution of some trace and major elements in sediments of the Cávado estuary (Esposende, Portugal). Mar Pollut Bull 99: 305-311

Gredilla A, Fdez-Ortiz de Vallejuelo S, de Diego A, Arana G, Stoichev T, Amigo JM, Wasserman JC, Botello AV, Sarkar SK, Schäfer J, Moreno C, de la Guardia M, Madariaga JM (2015b) A chemical status predictor. A methodology based on World-Wide sediment samples. J Environ Manage 161: 21-29

Ho HH, Swennen R, Van Damme A (2010) Distribution and contamination status of heavy metals in estuarine sediments near Cua Ong Harbor, Ha Long Bay, Vietnam. Geol Belg 13: 37-47

Huang J-H, Huang F, Evans L, Glasauer S (2015) Vanadium: Global (bio)geochemistry. Chem Geol 417: $68-89$

Kennish MJ (1996) Practical Handbook of Estuarine and Marine Pollution. Boca Raton, CRC Press.

Kim EH, Mason RP, Porter ET, Soulen HL (2004) The effect of resuspension on the fate of total mercury and methyl mercury in a shallow estuarine ecosystem: a mesocosm study. Mar Chem 86: $121-137$

Laurier FJG, Cossa D, Gonzalez JL, Breviere E, Sarazin G (2003) Mercury transformations and exchanges in a high turbidity estuary: The role of organic matter and amorphous oxyhydroxides. Geochim Cosmochim Acta 67: 3329-3345

Lopes JF, Silva C (2006) Temporal and spatial distribution of dissolved oxygen in the Ría de Aveiro lagoon. Ecol Model 197: 67-88

Lopez P, Navarro E, Marce R, Ordoñez J, Caputo L, Armengol J (2006) Elemental ratios in sediments as indicators of ecological processes in Spanish reservoirs. Limnetica 25: 499-512

Martinez-Ruiz F, Kastner M, Gallego-Torres D, Rodrigo-G!amiz M, Nieto-Moreno V, Ortega-Huertas M (2015) Paleoclimate and paleoceanography over the past 20,000 yr in the Mediterranean Sea Basins as indicated by sediment elemental proxies., Quaternary Sci Rev 107: 25-46

Martins MVA, Mane MA, Frontalini F, Santos JF, da Silva FS, Terroso D, Miranda P, Figueira R, Laut LLM, Bernardes C, Filho JGM, Coccioni R, Dias JMA, Rocha F (2015) Early diagenesis and clay mineral adsorption as driving factors of metal pollution in sediments: the case of Aveiro Lagoon (Portugal), Environ Sci Pollut Res 22: 10019-10033

Martins VA, Frontalini F, Tramonte KM, Figueira RC, Miranda $P$, Sequeira $C$, Fernández-Fernández S, Dias JA, Yamashita C, Renó R, Laut LL, Silva FS, Rodrigues MA, Bernardes C, Nagai R, Sousa SH, Mahiques M, Rubio B, Bernabeu A, Rey D, Rocha F (2013) Assessment of the health quality of Ria de Aveiro (Portugal): heavy metals and benthic foraminifera, Mar Pollut Bull 70: 18-33

McLusky DS, Elliot M (2004) The Estuarine Ecosystem (ecology, threats and management). Oxford University Press, Oxford 
Mil-Homens M, Costa AM, Fonseca S, Trancoso MA, Lopes C, Serrano R, Sousa R (2013) Characterization of Heavy-Metal Contamination in Surface Sediments of the Minho River Estuary by way of Factor Analysis. Arch Environ Contam Toxicol 64: 617-631

Pereira ME, Lillebø AI, Pato P, Válega M, Coelho JP, Lopes CB, Rodrigues S, Cachada A, Otero M, Pardal MA, Duarte AC (2009) Mercury pollution in Ria de Aveiro (Portugal): a review of the system assessment. Environ Monit Assess 155: 39-49

Perez L, Garcia-Rodriguez F, Hanebuth TJJ (2016) Variability in terrigenous sediment supply offshore of the Río de la Plata (Uruguay) recording the continental climatic history over the past 1200 years. Clim Past 12: 623-634

Prego R, Cobelo-Garcia A (2003) Twentieth century overview of heavy metals in the Galician Rias (NW Iberian Peninsula). Environ Pollut 121: 425-452

R Core Team (2014) R: A language and environment for statistical computing. R Foundation for Statistical Computing, Vienna, http://www.R-project.org/

Rimmer SM (2004) Geochemical paleoredox indicators in Devonian-Mississippian black shales, Central Appalachian Basin (USA). Chem Geol 206: 373-391

Rudnick RL, Gao S (2003) Composition of the continental crust. In: Rudnick RL, Holland HD, Turekian KK (eds) Treatise on Geochemistry, Vol. 3, Elsevier, p. 1-64

Russell FE, Boyle, JF, Chiverrell RC (2019) NIRS quantification of lake sediment composition by multiple regression using end-member spectra. J Paleolimnol 62: 73-88

Stoichev T, Espinha Marques J, Almeida CM, de Diego A, Basto MCP, Moura R, Vasconcelos VM (2017) Simple statistical models for relating river discharge with precipitation and air temperatures - case study of River Vouga (Portugal). Front Earth Sci 11: 203-213

Stoichev T, Duran R, de Diego A, Vasconcelos VM (2020) Modeling phaeopigment concentrations in water from a shallow mesotrophic lagoon. Water Environ Res, 92: 612-621

Stoichev T, Tessier E, Almeida CM, Basto MCP, Vasconcelos VM, Amouroux D (2018) Flux model to estimate the transport of mercury species in a contaminated lagoon (Ria de Aveiro, Portugal). Environ Sci Pollut Res 25: 17371-17382

Stoichev T, Tessier E, Amouroux D, Almeida CM, Basto MCP, Vasconcelos VM (2016) Multiple regression analysis to assess the role of plankton on the distribution and speciation of mercury in water of a contaminated lagoon. J Hazard Mater 318: 711-722

Stoichev T, Tessier E, Coelho JP, Lobos Valenzuela MG, Pereira ME, Amouroux D (2019) Multiple regression analysis to assess the spatial distribution and speciation of mercury in surface sediments of a contaminated lagoon. J Hazard Mater 367: 715-724

Tarasov DA, Buevich AG, Sergeev AP, Shichkin AV (2018) High variation topsoil pollution forecasting in the Russian Subarctic: Using artificial neural networks combined with residual kriging. Appl Geochem 88: 188-197

Telfeyan K, Breaux A, Kim J, Cable JE, Kolker AS, Grimm DA, Johannesson KH (2017) Arsenic, vanadium, iron, and manganese biogeochemistry in a deltaic wetland, southern Louisiana, USA. Mar Chem 192: 32-48 
Thibault de Chanvalon A, Metzger E, Mouret A, Knoery J, Chiffoleau J-F, Brach-Papa C (2016) Particles transformation in estuaries: Fe, Mn and REE signatures through the Loire Estuary. $\mathrm{J}$ Sea Res $118:$ 103-112

Tribovillard N, Algeo TJ, Lyons T, Riboulleau A (2006) Trace metals as paleoredox and paleoproductivity proxies: An update. Chem Geol 232: 12-32

Turner A (2000) Trace metals contamination in sediments from UK estuaries: an empirical evaluation on the role of hydrous iron and manganese oxides. Estuar Coast Shelf Sci 50: 355-371

Velez C, Freitas R, Soares A, Figueira E (2016) Bioaccumulation Patterns, Element Partitioning and Biochemical Performance of Venerupis corrugata from a Low Contaminated System. Environ Toxicol 31: 569-583

Yücesoy F, Ergin M (1992) Heavy metal geochemistry of surface sediments from the southern Black Sea shelf and upper slope. Chem Geol 99: 265-287 
Fig. 1. Map of (a) Localization of the Aveiro Lagoon (Atlantic coast, Portugal) (b) Aveiro Lagoon with the sampling points. Each point is characterized by distances $\left(d_{S}, d_{M}, d_{R}\right)$ within the simplified border (hyphen line) to contamination source (S), to the lagoon mouth $(\mathbf{M})$ and to a reference point $\mathbf{R}$, respectively (c) Laranjo Bay with the sampling points.

Fig. 2. Dependence of concentrations of metals $[\mathrm{Me}]$ in surface sediments from the Aveiro Lagoon on the distance to the contamination source $\left(d_{s}\right)$; (a) Co, $\mathrm{Li}, \mathrm{As}$, $\mathrm{Cu}, \mathrm{Zn}$; (b) Ni, Pb, V, Ba, Cr.

Fig. 3. Contour plot $\left(\mathrm{mmol} \mathrm{kg}^{-1}\right)$ of $(\mathbf{a}, \mathbf{c}, \mathbf{e}, \mathbf{g})$ model values and $(\mathbf{b}, \mathbf{d}, \mathbf{f}, \mathbf{h})$ experimental values for concentrations of $(\mathbf{a}, \mathbf{b}) \mathrm{As},(\mathbf{c}, \mathbf{d}) \mathrm{Cu},(\mathbf{e}, \mathbf{f}) \mathrm{Zn}$ and $(\mathbf{g}, \mathbf{h})$ $\mathrm{Ni}$ in surface sediments (Aveiro Lagoon). A specific geochemical function $\mathrm{f}_{\text {geo }}$ (on y axis) is defined for each element (Eqs. 17, 21-24) and separated statistically from geographical distance function (on $x$ axis); $d_{R}$ : distance to reference point, $d_{\mathrm{s}}$ : distance to contamination source.

Fig. 4. Contour plot $\left(\mathrm{mmol} \mathrm{kg}^{-1}\right)$ of $(\mathbf{a}, \mathbf{c}, \mathbf{e}, \mathbf{g})$ model values and $(\mathbf{b}, \mathbf{d}, \mathbf{f}, \mathbf{h})$ experimental values for concentrations of $(\mathbf{a}, \mathbf{b}) \mathrm{Pb},(\mathbf{c}, \mathbf{d}) \mathrm{V},(\mathbf{e}, \mathbf{f}) \mathrm{Ba}$ and $(\mathbf{g}, \mathbf{h})$ $\mathrm{Cr}$ in surface sediments (Aveiro Lagoon). A specific geochemical function $\mathrm{f}_{\text {geo }}$ (on y axis) is defined for each element (Eqs. 17, 26-29) and separated statistically from geographical distance function (on $x$ axis); $d_{R}$ : distance to reference point, $d_{s}$ : distance to contamination source. 
Fig. 5. Dependence of (a, b) enrichment index (EI) and (c, d) enrichment factor (EF) on the distance $\left(d_{s}\right)$ to the contamination source for metals/metalloids in surface sediments (Aveiro Lagoon): (a) Ba, V, Cr, Ni; (b) As, Cu, Zn; (c) Li, Ba, V, Cr, Ni, Co; (d) As, $\mathrm{Cu}, \mathrm{Zn}, \mathrm{Pb}$.

Fig. 6. Dependence of the enrichment factor (EF) for metals/metalloids $(\mathrm{Me})$ on (a, c) $\mathrm{EF}$ for $\mathrm{Mn}$ and on (b, d) organic carbon (OC) content for surface sediments (Aveiro Lagoon). The results for $\mathrm{As}, \mathrm{Cu}, \mathrm{Zn}$ and $\mathrm{Pb}$ from Laranjo Bay are excluded; (a, b) Ba, $\mathrm{Zn}, \mathrm{Cu}, \mathrm{Cr}, \mathrm{Pb}$ and (c, d) Co, Ni, V, As.

Fig. 7. Dependence of the ratio between concentrations of metals/metalloids [Me] and $\mathrm{Mn}$ as a function of $\mathrm{V} / \mathrm{Co}$ ratio in surface sediments (Aveiro Lagoon). The results for $\mathrm{As}, \mathrm{Cu}, \mathrm{Zn}$ and $\mathrm{Pb}$ from Laranjo Bay are excluded; (a) $\mathrm{Ba}, \mathrm{Zn}, \mathrm{Cu}, \mathrm{Cr}$, $\mathrm{Pb} ;(\mathbf{b}) \mathrm{Co}, \mathrm{Ni}, \mathrm{V}$, As. 
Table 1 Average values (bold), standard deviations and ranges (italic) for fine fraction $(<0.63$ $\mu \mathrm{m}, \mathrm{FF}, \%)$ and concentrations of organic carbon (OC, \%), total carbon (TC, \%), organic matter (OM, \%, loss on ignition) and metals/metalloids $\left(\mathrm{mmol} \mathrm{kg}^{-1}\right)$ in surface sediments from Laranjo Bay $(n=7)$ and from the other part of the Aveiro Lagoon $(n=25$ for FF, OC, TC, OM and As; $n=24$ for the other elements). Local background levels (LBL) were calculated using 3s and 4 s criteria

\begin{tabular}{|c|c|c|c|c|}
\hline & Laranjo Bay & Aveiro Lagoon ${ }^{(a)}$ & LBL $(3 s)^{(b)}$ & LBL $(4 s)^{(b)}$ \\
\hline FF & $26.1 \pm 16.8(11.7-56.2)$ & $23.5 \pm 23.7(0-90.7)$ & 51.4 & 24.1 \\
\hline OC & $3.0 \pm 1.3(1.3-4.5)$ & $1.4 \pm 1.1(0.05-3.7)$ & 3.8 & 1.8 \\
\hline TC & $3.2 \pm 1.0(1.8-4.3)$ & $1.7 \pm 1.1(0.07-3.4)$ & 3.6 & 2.0 \\
\hline OM & $3.7 \pm 2.1(1.2-6.0)$ & $3.0 \pm 2.6(0.4-11.2)$ & 5.6 & 3.1 \\
\hline $\mathrm{Ca}$ & $46.7 \pm 13.1(33.7-72.9)$ & $71.8 \pm 42.9(23.7-202.7)$ & 100.0 & 66.1 \\
\hline Al & $1689 \pm 433(1111-2296)$ & $875 \pm 553(52-1815)$ & 1811 & 1059 \\
\hline Mn & $2.68 \pm 0.41(2.28-3.42)$ & $2.49 \pm 0.84(0.87-4.55)$ & 3.41 & 2.53 \\
\hline $\mathrm{Fe}$ & $382 \pm 126$ (206-589) & $219 \pm 144(<L O Q-555)$ & 449 & 256 \\
\hline Co & $0.11 \pm 0.02(0.08-0.14)$ & $0.07 \pm 0.03(0.01-0.13)$ & 0.12 & 0.075 \\
\hline Li & $20.5 \pm 3.4(14.3-24.0)$ & $10.0 \pm 6.5(0.50-24.6)$ & 21.2 & 12.4 \\
\hline As & $0.86 \pm 0.49(0.42-1.79)$ & $0.17 \pm 0.07(0.10-0.40)$ & 0.65 & 0.27 \\
\hline $\mathrm{Cu}$ & $0.57 \pm 0.30(0.28-1.18)$ & $0.15 \pm 0.10(0.005-0.39)$ & 0.47 & 0.25 \\
\hline Zn & $2.89 \pm 1.28(1.47-5.34)$ & $0.77 \pm 0.52(0.03-2.66)$ & 2.69 & 1.25 \\
\hline $\mathrm{Ni}$ & $0.30 \pm 0.13(0.16-0.55)$ & $0.14 \pm 0.08(0.003-0.27)$ & 0.27 & 0.18 \\
\hline $\mathrm{Pb}$ & $0.083 \pm 0.050(0.034-0.187)$ & $0.024 \pm 0.024(0.002-0.106)$ & 0.076 & 0.038 \\
\hline $\mathbf{V}$ & $0.73 \pm 0.18(0.49-0.96)$ & $0.44 \pm 0.26(0.04-0.88)$ & 0.82 & 0.51 \\
\hline $\mathrm{Ba}$ & $0.87 \pm 0.19(0.63-1.15)$ & $0.55 \pm 0.30(0.08-1.07)$ & 0.95 & 0.62 \\
\hline $\mathrm{Cr}$ & $0.64 \pm 0.20(0.42-1.00)$ & $0.35 \pm 0.19(0.03-0.68)$ & 0.67 & 0.41 \\
\hline
\end{tabular}

(a) Samples 1-5 and LAR are excluded (Fig. 1c); ${ }^{\text {(b) }}$ LBL calculated according to Gredilla et al. (2015b);

Fe in sample BAR in summer could not be quantified (<LOQ). 
Table 2 Comparison of local background levels ( $\mathrm{LBL}, \mathrm{mmol} \mathrm{kg}^{-1}$ ) of metals/metalloids in marine and estuarine sediments

\begin{tabular}{|c|c|c|c|c|c|c|c|}
\hline & Aveiro Lagoon ${ }^{\text {(a) }}$ & $\begin{array}{l}\text { Cávado estuary } \\
\text { (Portugal) }^{\text {(b) }}\end{array}$ & $\begin{array}{l}\text { Shelf, } \\
\text { SW Iberian (c) }\end{array}$ & $\begin{array}{l}\text { Galicia estuaries } \\
\text { NW Iberian }^{(d)}\end{array}$ & $\begin{array}{l}\text { Loire estuary } \\
\text { (France) }^{(e)}\end{array}$ & World $^{(f)}$ & $\mathrm{UCC}^{(\mathrm{g})}$ \\
\hline Co & $0.075-0.12$ & $0.078-0.13$ & & $0.20-0.22$ & & $0.27(0.17-0.66)$ & 0.29 \\
\hline $\mathbf{L i}$ & $12.4-21.2$ & & & & & & 3.46 \\
\hline As & $0.27-0.65$ & $0.067-0.10$ & & & 0.26 & $0.21(0.16-0.27)$ & 0.064 \\
\hline $\mathrm{Cu}$ & $0.25-0.47$ & $0.96-1.47$ & 0.33 & $0.31-0.55$ & 0.31 & $0.43(0.14-1.81)$ & 0.44 \\
\hline $\mathrm{Zn}$ & $1.25-2.69$ & $1.56-2.17$ & 0.99 & $1.84-2.08$ & 1.43 & $1.48(0.61-2.68)$ & 1.02 \\
\hline $\mathrm{Ni}$ & $0.18-0.27$ & $0.18-0.27$ & & $0.53-0.65$ & 0.66 & $0.51(0.20-1.35)$ & 0.80 \\
\hline $\mathbf{P b}$ & $0.038-0.076$ & $0.15-0.19$ & 0.13 & $0.24-0.38$ & 0.17 & $0.16(0.053-0.35)$ & 0.082 \\
\hline V & $0.51-0.82$ & $0.18-0.25$ & & & 2.39 & & 1.90 \\
\hline $\mathrm{Ba}$ & $0.62-0.95$ & & & & & & 4.57 \\
\hline $\mathrm{Cr}$ & $0.41-0.67$ & $0.44-0.64$ & & $0.58-1.04$ & 1.91 & $0.77(0.15-1.67)$ & 1.77 \\
\hline
\end{tabular}

(a) this study; range of LBL determined by 3 s and 4 s methods according to Gredilla et al. 2015b

(b) calculated from Gredilla et al. 2015a; range of LBL determined by 3s and 4s methods according to Gredilla et al. $2015 b$

(c) Corredeira et al. 2008

(d) Carballeira et al. 2000

(e) Coynel et al. 2016

(f) Birch 2017; mean and range of LBL in coastal and marine sediments

(g) Rudnick and Gao 2003; UCC: upper continental crust 
Table 3 Values for the intercept $c_{0}^{\prime}$ and the slope $c_{1}^{\prime}$ and the coefficient of determination $R^{2}$ for As, Ba, Co, Cr and V (Eq. 34a). Data from Laranjo Bay (Fig. 1c) for As were removed

\begin{tabular}{l|lll}
\hline $\boldsymbol{M e}$ & \multicolumn{1}{|c}{$\boldsymbol{c}_{\mathbf{0}}^{\prime} \times \mathbf{1 0}^{-\mathbf{5}}$} & \multicolumn{1}{c}{$\boldsymbol{c}_{\mathbf{1}}^{\prime} \times \mathbf{1 0}^{-\mathbf{5}}$} & $\boldsymbol{R}^{2}$ \\
\hline $\mathrm{As}$ & 0 & $7510 \pm 452$ & $0.88(n=24)$ \\
$\mathrm{Ba}$ & $51.4 \pm 1.8$ & $3655 \pm 241$ & $0.89(n=31)$ \\
$\mathrm{Co}$ & $6.73 \pm 0.32$ & $472 \pm 43$ & $0.81(n=31)$ \\
$\mathrm{Cr}$ & $38.2 \pm 1.5$ & $866 \pm 204$ & $0.38(n=31)$ \\
$\mathrm{V}$ & $47.5 \pm 1.7$ & $880 \pm 223$ & $0.34(n=31)$ \\
\hline
\end{tabular}

Abbreviations: Me: metal/metalloid; EF: Enrichment Factor; LBL: Local

$$
\text { Background Level; } \quad c_{0}^{\prime}=c_{0}\left(\frac{[\mathrm{Me}]}{[\mathrm{Al}]}\right)_{L B L} \quad c_{1}^{\prime}=c_{1}\left(\frac{[\mathrm{Me}]}{[\mathrm{Mn}]}\right)_{L B L}
$$



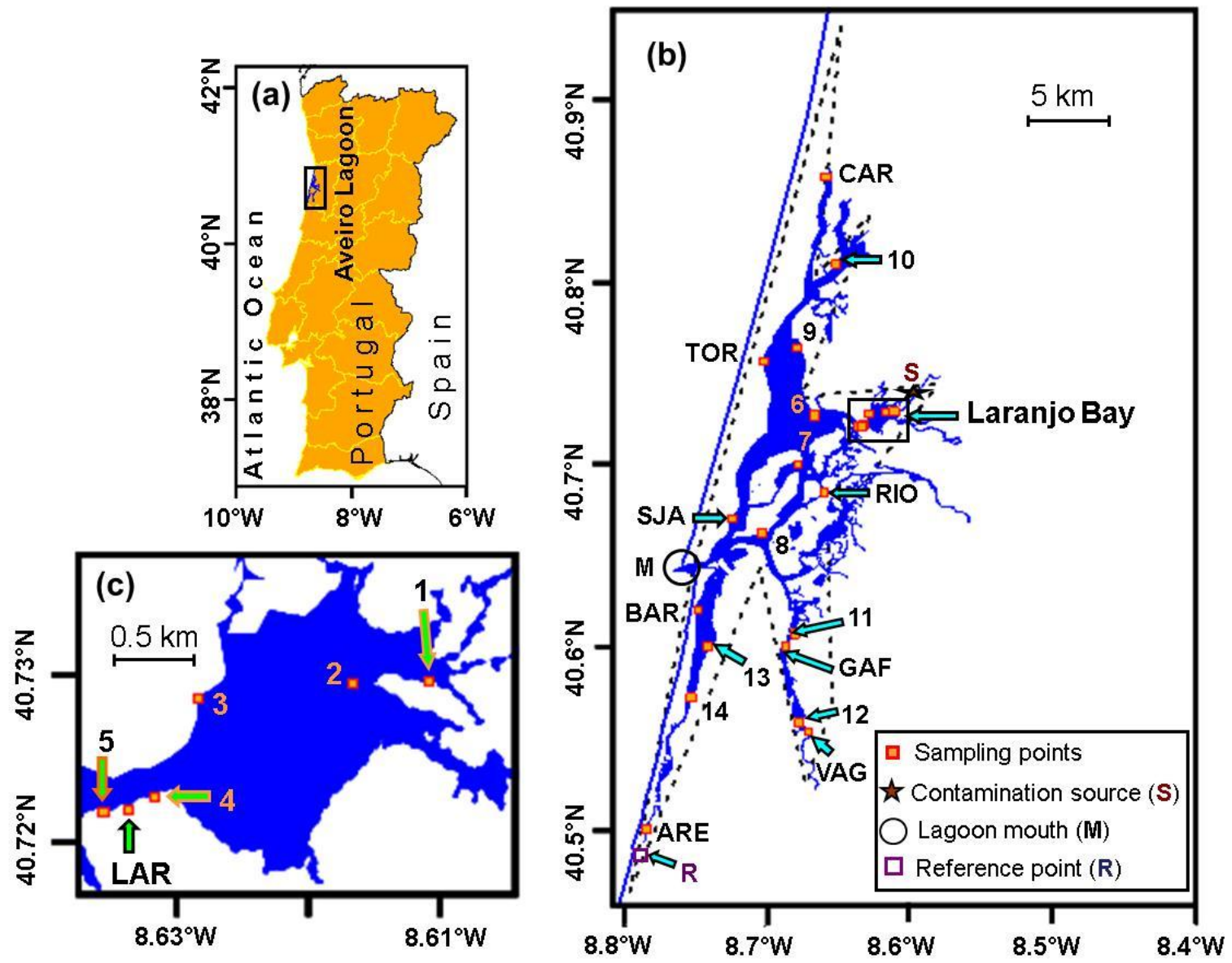

Fig. 1 


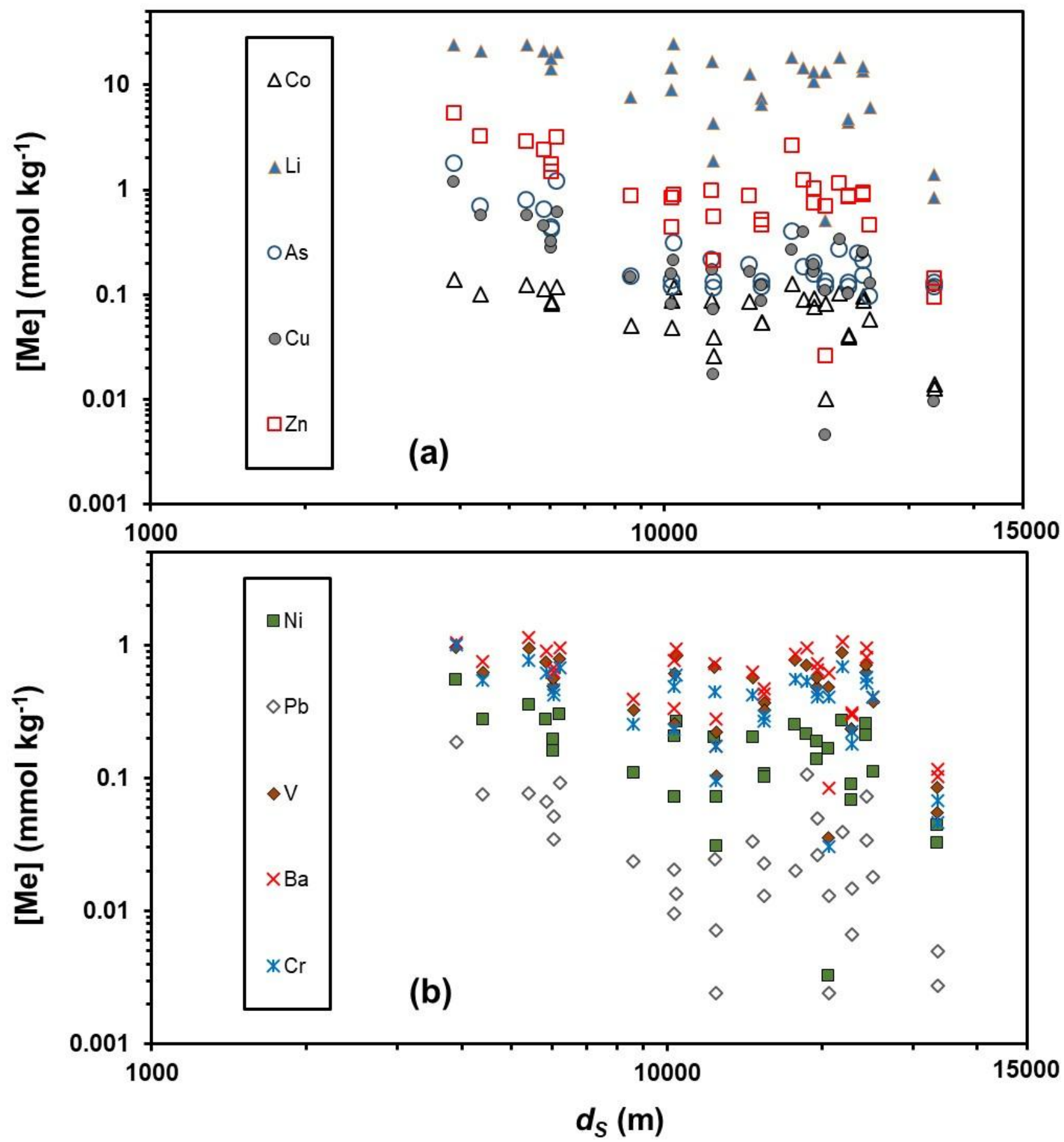

Fig. 2 

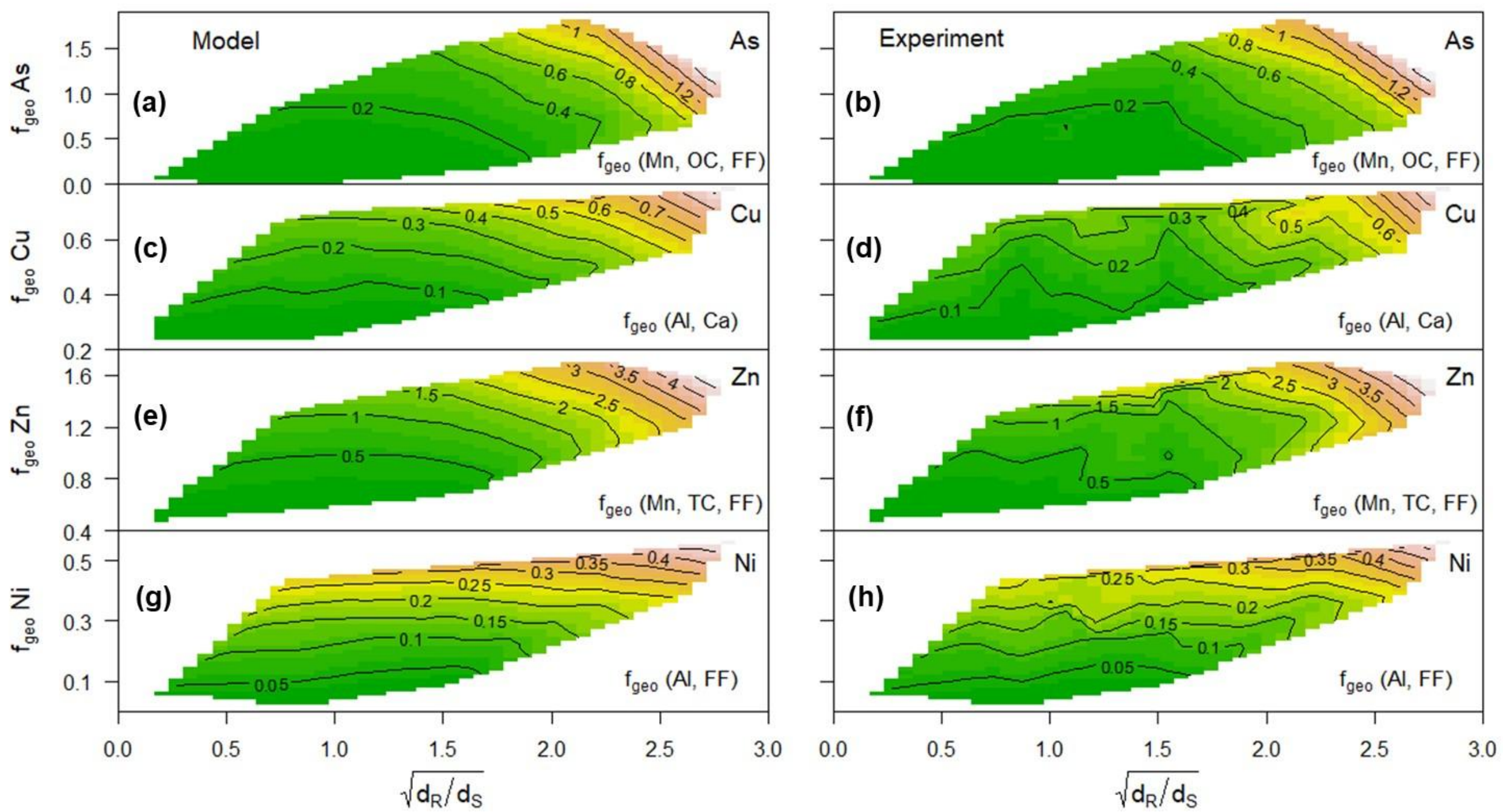

Fig. 3 

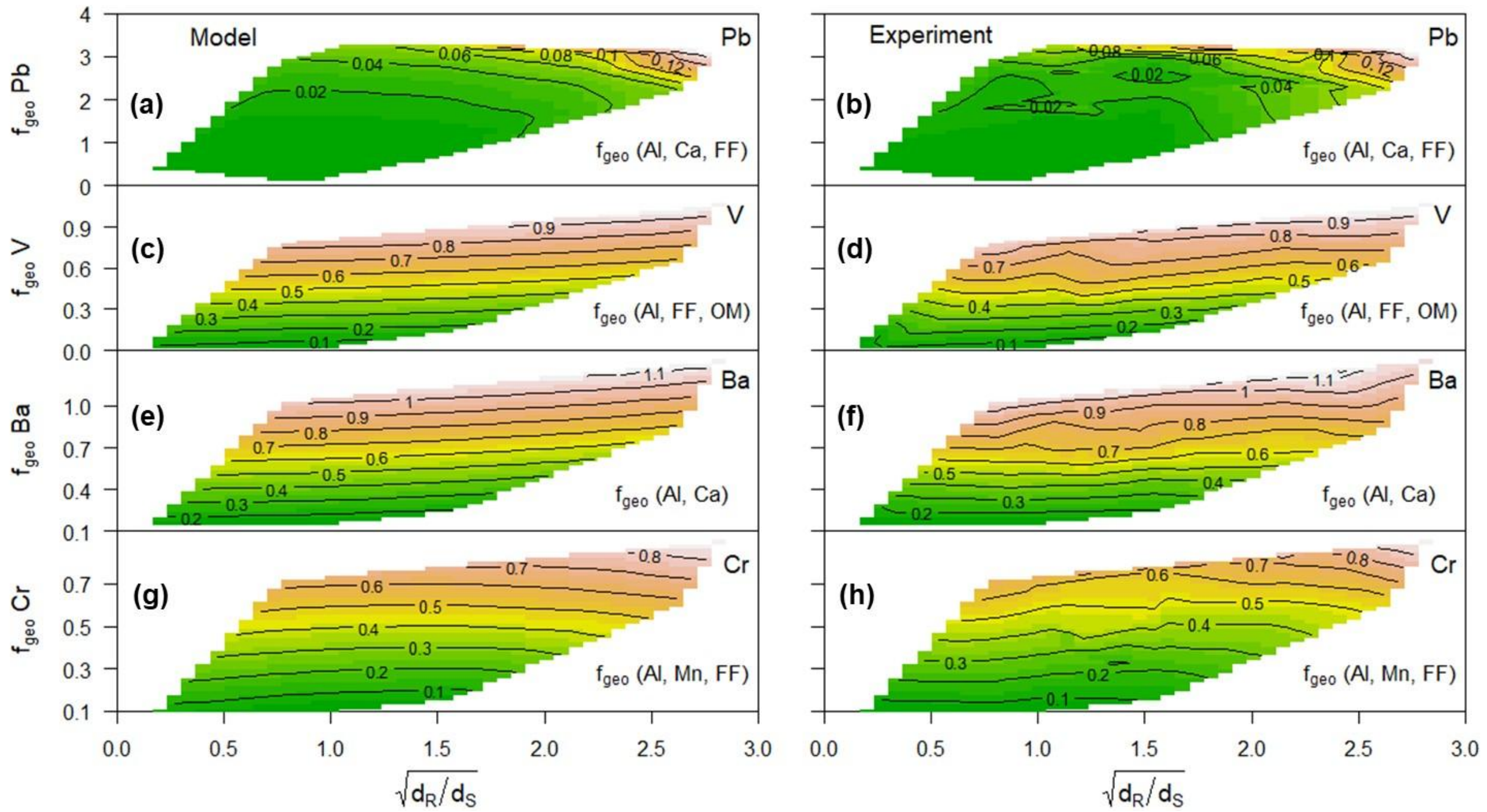

Fig. 4 
Figure 5
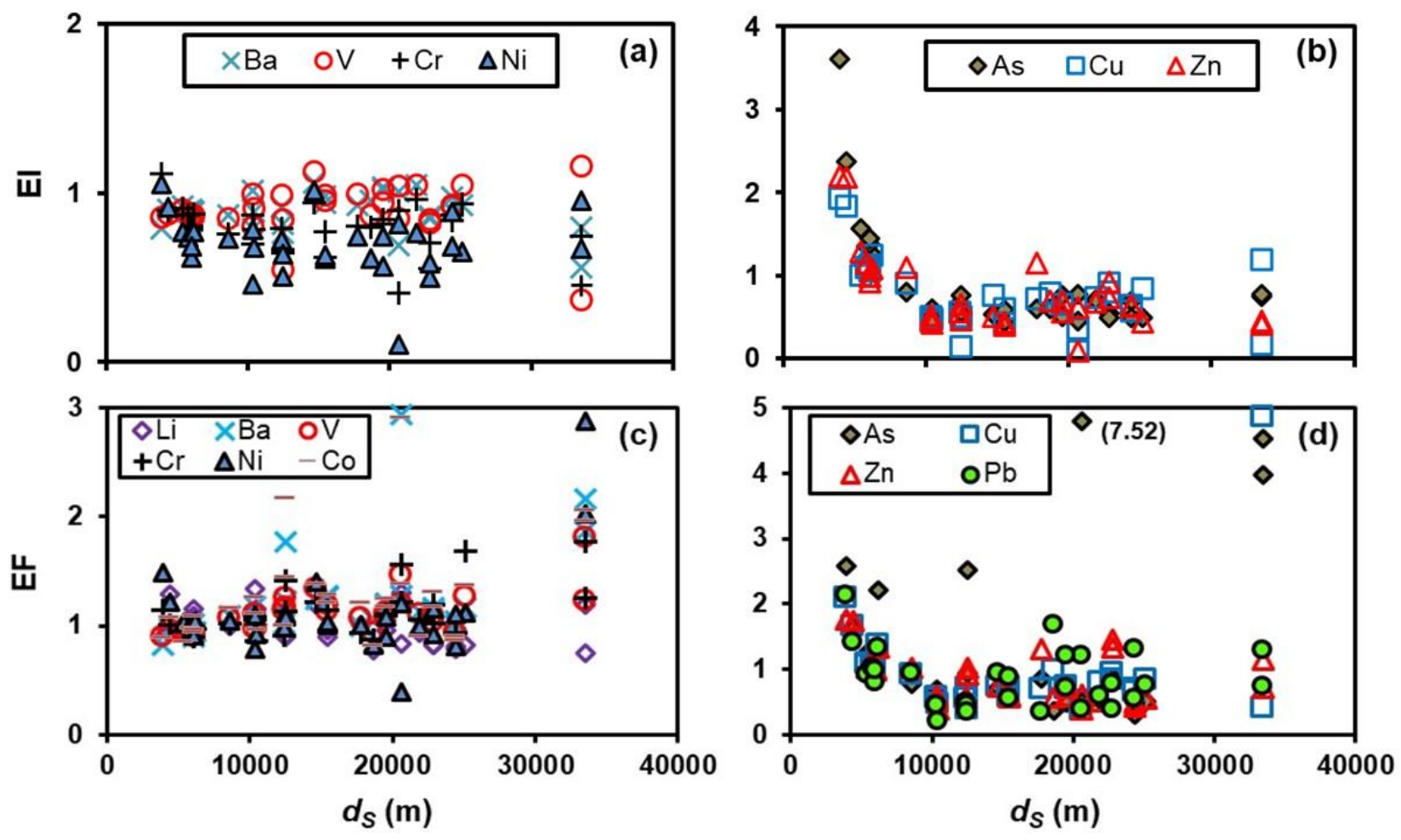

Fig. 5 

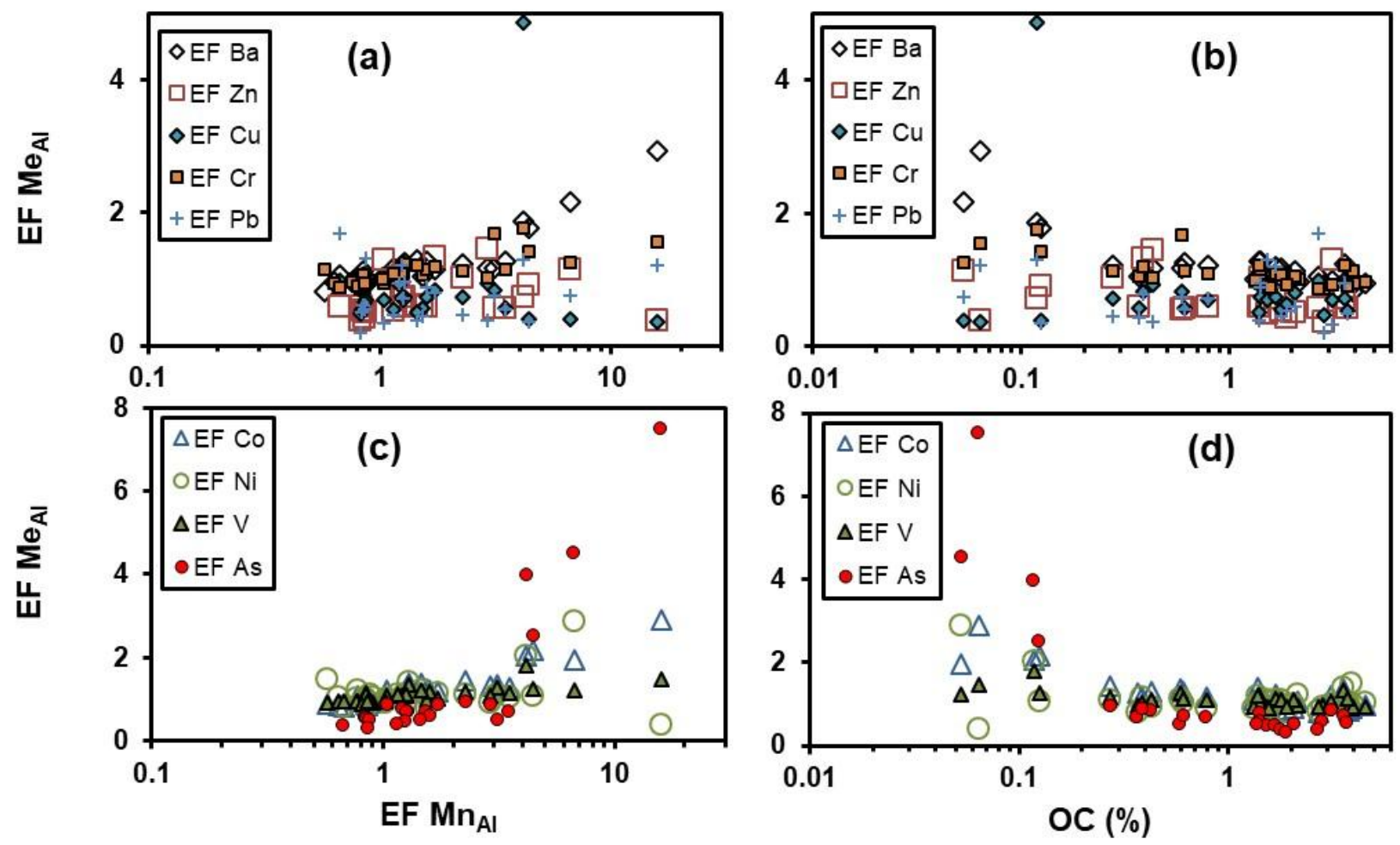

Fig.6 
Figure 7
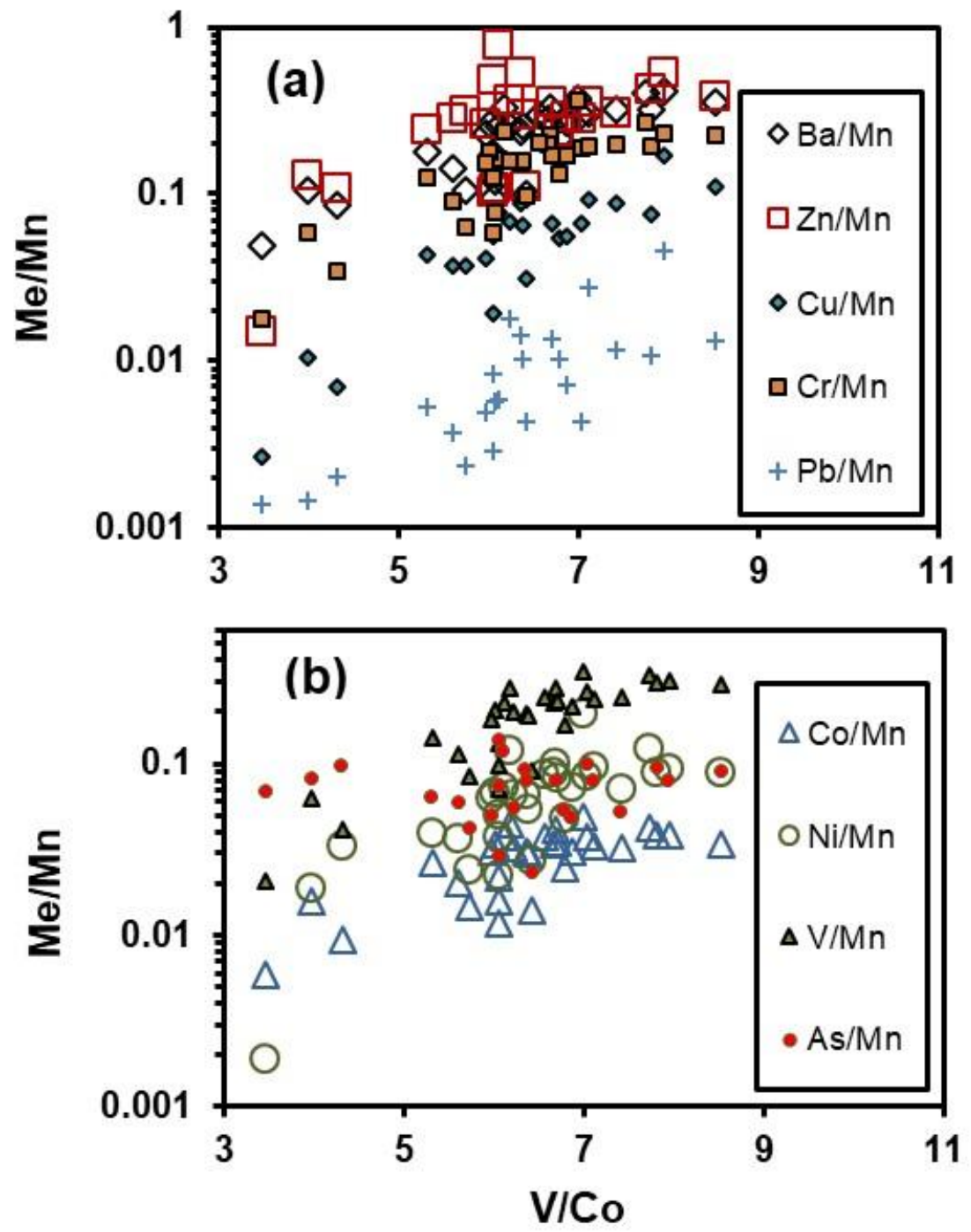

Fig. 7 